\title{
URBAN PROBLEMATIC OF CULTURAL MANAGEMENT IN HISTORICAL FRAGMENTS IN ISTANBUL: A CASE STUDY IN FENER-BALAT AND SÜLEYMANIYE
}

\author{
CANAN GÜLSEREN İNAN \\ Department of Anthropology, İstanbul Kavram Vocational College, Turkey
}

\begin{abstract}
The aim of this study is to scrutinize cultural management in terms of control, regulations and sociocultural dynamics in the projects of urban transformation/gentrification including the historical and cultural areas in İstanbul. To analyze the cultural politics of urban transformation, along with the socio-spatial impacts of the process of gentrification, Süleymaniye and Fener-Balat have been chosen as two districts that were included in the World Heritage List due to the historical-cultural patterns they display. Evidently, the social ethos, created through Neo-Ottomanist approaches in urban renewal processes, is unregulated. Thus, it is necessary to examine the apparatuses of power in the matter of sustaining the representations of historical and cultural identity, which make up collective memory in terms of identity and space construction. It is assumed that the dynamics of urban transformation have also been transforming collective consciousness based on historicity. In this context, concepts such as urban alienation, mental unmappability, the emptying of minds and cultural uprooting, have enriched the theoretical construction of the study in analyzing the management of collective memory that is intricately tied to the process of global urbanization. With the institutionalization of centralized politics, we are witnessing the instrumentalization of urban space and the placement of urban transformation on a strictly market-based trajectory with no room for an alternative path. Moreover, the relationship between symbolic capital and collective memory as the basis of cultural heritage seems to have been ruptured. Ultimately, what is at risk is the ideal of a human-centered, democratic community, encompassing contrapuntal ensembles (different narratives based on historicity that could only be interpreted via each other and make sense related with each other in their own cultural representations/specifications) and polyphonic cultural constituents. Along with the paradigm of neoliberal urbanization came the new phenomenon of urban space design, mediatization of culture and collective memory. Expressed in the language of consumption, designed to fit packaged socio-spatial practices and emotions, it is argued that we now entered a post-emotional socialization stage.
\end{abstract}

Keywords: urban transformation, gentrification, cultural management, collective memory, postemotionalism.

\section{INTRODUCTION}

This study's main point of departure is the contention that urban transformation is a highly complex process that goes beyond the realms of urban planning, architecture, landscape architecture, and civil engineering. Rather, it is intricately and increasingly linked to the political, economic, social, historical, and cultural contexts. The initial, unrefined questions that led to this research, therefore, are how urban transformation in Turkey is planned and carried out, and how it affects the residents of the transformed neighbourhoods as the major stakeholders of the process. Specifically, considering the complex demographic structure of the historical neighbourhoods in Istanbul, it is presumed that the polyphonic communities in such neighbourhoods undergo a number of dramatic changes throughout the urban renewal and gentrification processes. Thus, how these changes are perceived by and what they mean to these communities and various other stakeholders of the urban transformation process (such as architects, state officials, and representatives of NGOs working in related fields), in general, and what these changes imply for cultural heritage, identity, and collective memory of the city, in particular, is the research question of this study. To facilitate a fuller 
understanding of both the phenomenon, the context, and the political, economic-social, and cultural implications of urban transformation in Istanbul, Süleymaniye and Fener-Balat are chosen as the two cases to be explored in this study since it was anticipated that these neighbourhoods would reveal the relations between cultural policies and public sphere in various ways.

Süleymaniye was declared a SİT area (protected area) in 1977 and was included in World Heritage List by UNESCO in 2006. This intensely historical area makes the dynamics of urban transformation clearly visible in the aspects of the cultural management and the impacts of renewals over the residents. At present, the neighbourhood is being transformed into something 're-historicised' with a kind of neo-identity.

On the other hand, the Rehabilitation Project performed in Fener-Balat in the aftermath of the 1996 Habitat Conference by the support of European Commission and UNESCO is considered to be a significant case in urban planning despite the inadequacies and the political controversies it caused. This piloting performance particularly suggests an alternative to decreasing the house sales through pre-set regulations such as gifting. Clearly, it would rehabilitate the quality of life for the local people and the initiatives that preserve and sustain the historic-cultural identity of the urbanscape, instead of the rapid take-overs through enacted renewals in the mahalles (small-scale neighbourhood) such as Süleymaniye, Sulukule and Tarlabaşı. The reasons as to why such urban renewals initially performed in Fener-Balat as the prominent ones are not taken into consideration in today's urban interventions are analyzed in this study.

\section{METHODOLOGY}

Analyzing how the "gentrifying" actors and the residents who are undergoing gentrification are positioned in the historical neighbourhoods, fieldwork for this study was carried out using direct observation, participant observation, and in-depth interviews as the data collection methods. Study participants have been asked open-ended questions. The instrumental case study design was followed for the study employing empirical approach and reflexive method. To analyze the cultural politics of urban transformation, along with the socio-spatial impacts of the process of gentrification, Süleymaniye and Fener-Balat have been chosen as two districts that were included in World Heritage List due to the historical-cultural patterns they display.

Interview data for this study were collected between April 2012 and January 2013. Throughout my fieldwork, I had 22 interviewees in Fener-Balat and Süleymaniye, 14 of whom are the residents and/or shop owners of the mahalle and 8 of whom are the authorities. At the beginning of my fieldwork, I had informal conversations in the areas while strolling and observing around and I met my contact people. Then, I adopted the snowball method to gather the necessary data in Fener-Balat and Süleymaniye. I also interviewed particular authorities, setting appointments with them. Dr. Halil Onur, Architect and the Head of Field Management of İstanbul's Protected Areas, as well as the Head of KUDEB (Conservation Implementation and Control Bureau) was one of my interviewees. Dr. Halil Onur is a key figure in urban transformation in İstanbul. Onur not only leads the renewal projects but also makes architectural plans.

\section{CONCLUSION}

\subsection{Globalization, culture and urbanization}

Cultural management through urban transformation and gentrification in the historical areas is significant because the process of 'gentrification' indicates some kind of restructuring of 
collective cultural references in social life. Besides, urban spaces have been replacing the states in their role of constructing social identities [1]. This fact clearly points out a renaissance, signifying neoliberal urbanization.

The social class has been reformed through the trajectories of neoliberal economy models, as globalization defines individuals by the way they consume, not produce, which results in the middle class being demoted to a lower class. Therefore, the gap between the lower and upper class has increased [2]. According to Hernandez and Marti [3], cultural homogenization and heterogenization manifest, having diversities in different global realms, differential characteristics of "deterritorialization" in contemporary cultural globalization.

Social space occupied by hegemonic relations, class clashes, class and culture shifts suggest some kind of urbanscape required to be read accordingly. As Deleuze and Guattari conceptualize, deterritorialization is one of the main issues subject to the process. Deterritorialization, considered a central feature of globalization, implies the growing presence of social forms of contact and involvement which go beyond the limits of a specific territory. Mediatization works as a preferential source of deterritorialization, while becoming a catalyst of other sources of deterritorialization (migrations, tourism, vast shopping centres, and economical transformations Paradoxically, deterritorialization also includes reterritorialized manifestations [3].

As shown by Baudrillard, in a consumer society, identities are more precious than people [4]. People consume those images, ideals, fantasies hidden behind commodities rather than commodities themselves. Undoubtedly, urban space has become commodity, a kind of "fantasmagoria" [5] and new social ethoses, then constructing new identities has been the drive of today's urbanization. For this reason, the process of urban transformation, which also includes interventions that historical-cultural entities undergo, encompasses transformation of collective memory.

Rather, reconstruction of narcissism or the aspiration for nostalgia points out the concept of "simulacra" as Baudrillard terms [4]. The term simply depicts the copies of the things that had no reality to begin with, or that no longer have an original. The notion of circle of life containing life-and-death, which also indicates what Baudrillard conceptualizes as the order of symbolic exchange, vanished in modern society owing to the capitalist order [4]. Hence, narcissism has become a proliferous fact that is commercialized as meta by consumer society just like the aspiration for nostalgia [6].

In every aspect, cities, which are taken under control, ripped and destroyed in terms of socialization like argued above, are now the spaces of decentralised production via signs, means of communication and code [4]. Yet, the system cannot abdicate the urban structure as the space of reproduction. It is because a central code means power. At this point, Baudrillard introduces a striking parallelism between urbanisation and economy: "City offers a vertical and horizontal expansion just like economy..." (translated by the author from [4]). Apart from the issue argued above, as the controlling strategy of code, the main pattern of urban space does no longer consist of labour of force, but procedural signs, which do indicate every phase of urban reproduction and retransformation in an inextricable way. Deleuze and Guattari's definition of the term deterritorialization is used and defined in a specific way. When referring to culture, anthropologists use the term deterritorialized to refer to weakening of ties between culture and place. This means the removal of cultural subjects and objects from a certain location in space and time. It implies that certain cultural aspects tend to transcend specific territorial boundaries in a world that consists of things fundamentally in motion.

Although this refers to culture changing, it does not mean that culture is looked at as an evolving process with no anchors. Also, often when one culture is changing, it is because 
another is being reinserted into different culture. At that moment, the deterritorializing process begins as the local culture is enveloped by the global community. Here, deterritorialization and reterritorialization are seamlessly conjoined; reterritorialization occurring immediately after, as the local community becomes a part of the global culture. This relates to the idea of a globalization of culture [7].

However, the deterritorialization of localized cultural experiences does not indicate an impoverishment of cultural interaction, but a transformation produced by the impact of the growing cultural transnational ties on the local realm. The relations amid our environment and our cultural activities, experiences and identities are transformed by globalization. Therefore, it suggests that it is jeopardising collective memory in a multi-cultural human geography and a historical urban space as in İstanbul rather than helping it to sustain, so there will no longer be the texture of "contrapuntal ensembles" in the global space, but possibly the transformed space and memories.

Frisby also introduces the mechanism in urban space where "traces of the memories have systematically been deleted" by means of instant-spatial inferences and transformations disabling us to experience the past and the present of metropolises, that is, as a result of the problem of emptying memories [8]. It can be predicated on today's urban interventions that the "chronotope" (integrated space-time in social flowing) of İstanbul, with the term Bakhtin introduces [9], and the 'language' coming to life through this chronotope will not only negate the logic of globalization, but also imply only the dystopia of that.

\subsection{Legal perspectives and international regulations on capital}

The concept of gentrification is also to be defined by the relation between the mediation of finance capital in the city and the social impact that the agents of cultural capital cause. Cultural possessions have now been commodified being transformed into symbolic capital through various historical narrations or "cultural capital" in Bourdieu's terminology, in creating "the global city" [10].

On the protection through renewal and the sustainable use of derelict historical and cultural immoveables, the law 5366 is questioned with respect to the 'real' definition of 'derelict' and feasibility in the zone. Residents are compelled to leave their places as a requirement of expropriation, which, in turn, is rooted in the fact that housing is still mediated as an instrument of speculation.

By the 1980s, under the influence of global political tendencies, Istanbul has been transformed into "a huge physical and cultural construction site" as a part of the global landscape [6]. The history, the geopolitical and the cultural values of the city have been used and/or abused by the governments and the bourgeoisie and the elite to gain a significant status in the world economy by maintaining the global urban project [11]. This was undoubtedly the case because global capital has shifted to metropolises, and urban space and the sectors related to urban practices also gave rise to cultural industries [10]. The actors who did not prefer to lead their lives on the peripheries of the city or did not have the chance to move thereabouts rejected the complications of the period. Then they started to buy those buildings, most of which are from the 19th century. This was taken into consideration with the urban renewal movement in the city and called gentrification [6].

Migration is another factor that played a significant role in the process of gentrification in İstanbul. Districts such as Cihangir, Kuzguncuk and Balat are regarded as the areas that were mostly inhabited by the Roums, the Armenians and the Jews, who left or were obliged to leave their mahalles and migrated. 


\subsection{Residents perspective on what legal and socio-cultural practices}

Connerton defined the term, "social memory", as "our experiences relating present depend on the knowledge of past to a great extent and the images of past function to institutionalize present social order commonly. We position the behaviours of actors through the references to their places in the actors' lifestories and position them according to their places within the history of that social environment" [12]. Connerton also puts forward the idea that individuals reproduce identity through these intricate narratives. Just like Halbwachs states, "Not only collective memory depends on social frames, the memories of individuals are also supported and defined by them" [12].

İstanbul, to Perouse [13], considered as a "world brand" by the empowered actors in a centralized status is being transformed into a stereotype object of tourism and a commodity instead of its urbanscapes being preserved in their local patterns and their own characteristics (case in point: İstanbul being promoted as the Cultural Capital of Europe in 2010). In other words, ignoring the historical disposition of the city, a Disneyesque İstanbul is being produced.

We are witnessing the instrumentalization of urban space and the placement of urban transformation on a strictly market-based practice. Centralized politics are institutionalized. At this juncture, centralization of settlement projects and the recently founded ministry (Ministry of Environment and Urbanization), signifies the empowerment of singular state administration. Nonetheless, current trends and developments in Europe, the Council of Europe released a table in 2000 showing broad trends in cultural heritage management. Firstly, for a definition of heritage, there should be a contextualized approach for individual sites and monuments as part of a larger whole which should essentially be taken into account for sustainability. Further, changeable management practices breed the understanding of heritage resource management as "the management of change" (6).

What stands out is that the cultural resistance and collective identity in Fener-Balat seem to be much more vivid than in Süleymaniye. For instance; Fener-Balat-Ayvansaray Derneği (FEBAYDER) as a Non-Governmental Organization (NGO) has strongly been protesting against gentrification and renewal projects, resulting in the court case won in 2013. Strikingly, there has been a distinctive aspiration and hope on the part of the residents for their Roum neighbours to come back and enjoy all the bayrams (national or religious fests) happily together again after the restorations implemented by UNESCO, which reminds us of the concept, "contrapuntal ensembles" borrowing from Said. Yet, some mahalleli think of leaving their places because they feel frustrated by the urban changes imposed by obscure and oppressive state tactics, and the corruption. In addition to that, a cafe owner in Fener reveals the impacts of post-emotional responses, Americanization, cultural homogenization as part of cultural deterritorialization and urban alienation with her brief expression: "We have lost our culture. The later westernization comes, the better the place is preserved. Some people doing research or something in this mahalle treat the people in the streets as circus animals. That's it."

\section{...The number of firm houses that are burnt has been on the increase since the renewals started and it is not only historical houses, but also large and firm buildings where a lot of people had worked together were demolished in order to be renewed...}

We were invited to Eminönü Municipality. We were given information that the historical houses should be restored according to the plan given by them or sold to them. If no, there would be expropriation. I suggested that they should come and talk to the mahalleli (local 
people living in the same neighbourhood). It wasn't something persuasive to us. There is no contact with the authorities. Some old mahalleli families from different cities had to leave their own mahalle holding their arms around me, weeping and saying, "I want to die here" while leaving..." [14].

Tarihi Süleymaniye Kurufasulyecisi (No. 25), Gazanfer explained "We become aware of the things only after works in renewal areas". Gazanfer also said he was so tired and sick of this restless waiting to be displaced sooner or later that he wanted to go somewhere just plain and peaceful, dramatically in a similar frustrated tone as Reşit Sarı, the owner of Tarihi Haliç İşkembecisi:

I have had enough of these uncertainties, I want to leave my hometown for Kazdağları or somewhere just to have peace of mind because I don't want to deal with these things in my mahalle anymore. So, I am selling my cafe, too, now. I was grown up with the Roum, we would go kiss hands and they would, too, during bayrams. No one feels safe and happy in Fener-Balat now. They give us too much stress even when there is a small usual problem like work license or something. For instance, my next-door friend had a problem with the officials from the municipality. Very soon, from Ministry of Finance to Ministry of Health, all the officials arrived there for a point check.

The process of gentrification in İstanbul has mainly been performed by means of ephemeral and instant spatial interventions as seen in Süleymaniye unlike the restoration / renewal works that suggest a preservation-based, integrated and sustainable project initiated by UNESCO in Fener and Balat. It is because, in a district like Süleymaniye, the old Ottoman Houses have been reimbued and reproduced with fully new interior decor and the architectural details apart from the facades which have been relatively preserved by retouches. Additionally, the mahalleli have had the experience of displacement, in other words, deterritorialization. The cultural pattern and the collective remembering peculiar to the culture of mahalle are enshrouded and deconstructed as well.

Süleymaniye Mosque and the complex of buildings adjacent to the mosque [külliye] built by Architect Sinan in the 16th century underwent inapt restorations and the acoustics was entirely damaged in 2012 [15]. On the other hand, "aesthetics of daily life" including the architectural style of the buildings, structures, as well as urban planning and designing was a public service for the Ottomans as Kafadar states.

According to 2012 UNESCO Report, there has been inadequate politics of tourism regarding integrity of the entity, main points of the outlook, and conservation of the silhouette for the Historic Peninsula. It was also stated that the fact reveals vague urban politics in the mahalles. Further, it was issued that there has been an uncontrollable expansion in the zone, but no management plan for the World Heritage as well as coordination among the national, local and administrative body [16].

Criticising the outcomes of 2008 and 2009 restorations briefly in the area, it was negatively reported by World Heritage Committee in 2013 that Süleymaniye in the protected zone could not be preserved following the renewals, also stating that it causes serious worries and most of the historic houses bought by a company did collapse (many houses burned down) and they were not restored. The ongoing restorations did not only offer a participationbasis performance but also many historic houses were not registered. Neither were the relieves and the structures. "The Mission concludes that despite much excellent repair and restoration of individual buildings and groups of buildings, the extent of deterioration, decay and demolition of Istanbul's Ottoman vernacular heritage is approaching crisis point. Formal Renewal areas as currently interpreted and implemented appear to be adding to the problem 
rather than facilitating a solution. Significant adverse impact on the Outstanding Universal Value has already been caused by the redevelopment of Sulukule and demolition in Ayvansaray" [17].

Urban renewals meant 'displacement' in general sense in Turkey and historic structures as in mahalles should be preserved and sustained rather than decentralising work places and constructions according to the UNESCO Report [18].

Apart from the argument above, the discourse constructed in the media advertisements for the newly rising living arrangements is elaborated by indicating the new "gated communities", in other words, "impacted ghettos" through the definitions, such as "elite and prestigious" lives. Rather, in this post-emotional realm, the language used refers to the newly "promised holy land" and the standardized social practices with the standardized emotions "packaged" beside them. In constructing the policies of identity and space, the language itself has become the oppressive form of cultural praxis.

The new perspective that I would attach to the back of Riesman's insight is this: The language-as-consumer-good is no longer primarily the carrier of rationally intended meanings, but now carries standardized emotions as well [21].

Moving from the point here, the fact of today's Kafkaesque alienation might be considered, more intensely in urbanscape rather than collective sensations. The notion underlied here also brings to mind the Disneyesque lifestyles in terms of standardizing/controlling both collective and individual consciousness by ruling all forms of creative interpretation, which have drastic impacts on socio-cultural capital and the ethos of it. Closely, supporting the theory of post-emotionalism, it is necessary to define what is genuine, which was inquired during the anti-cultural movement of 1960 s by the public.

An architect, urban theorist and planner, Korhan Gümüş was interviewed due to his urban projects performed and his self-presentation as the 'interface' between public voice and the institutional bodies in designing urbanscape. As an outstanding urban renewal case, according to Gümüş, an industrial region, such as Ruhr, could even be transformed into a metropolis by means of a local organization. Besides, a huge environmental rehabilitation is included within this organization as well. Actually, this huge and long-term project is performed by a local organization bringing such actors together who have very different priorities. What is aimed in Ruhr, which had been the most prominent industrial centre of Europe some short time ago, is not only a rehabilitating or a preserving project for industrial heritage, but also urbanizing an industrial area through a different urban semantics. Urbanizing, therefore, raises the issues of working on integrated and complicated spaces, refunctioning them, developing new architectural projects, establishing urban plans and making the relevant decisions, performing sub structural investments and managing all unlike what TOKİ (social housing construction company in collaboration with the government) does by cooping people up in hen-house like places.

However, safeguarding the diverse European heritage requires mutual understanding, respect and recognition of the cultural values of others, particularly in relation to the cultural identities and heritage of minority and vulnerable groups and the consideration of the common interest in European heritage [23].

For Pamuk, İstanbul, as a lost imperial capital, but not a lost cultural one, is full of the symbols and images of longing [24]. Apparently, it is a city of longing because of its past. The title of his novel also, 'hüzün' (sadness and melancholy) is that longing for the city. Having such an entrenched sensation and the identification peculiar to town, the city clearly becomes the very profound image in collective memory for İstanbulians to some extent. In reality, the city, at present, appears to be having a metamorphosis and transforming 
into a construction site, rather than a "cultural capital", owing to the process of gentrification and the architectural proposals.

\subsection{Perspective from developers when dealing with intervention programs (regeneration or renovation)}

Speaking of cultural management in urban renewals and transformations, Eyüp Muhçu (Chairman of Chamber of Architects) suggests local organizations that Aesthetical Board is included in [25]. It is because local organizations are rather significant in the restructuring that has some identity. "Our opinions were not inquired about risky areas in terms of earthquake. Consultancy firms have been given the authority of project making and auditing, but not building inspection firms. In fact, companies can not own the copyright for designing. Public opinion is not taken into consideration. We proposed a report about the subject mentioned above. There is a complication of authority in the aspect of planning processes" [25]. Pointing out the structural problem at the basis of urban transformation, Muhçu asserts that coordination, guidance and legal substructure are to be established and public opinion is to be considered rather than a centralized structure to be imposed [26].

Very importantly, to Muhçu, the matter is the right of property may be deforced by means of the law item, 6306, related to urban transformation. In case of the transformation for a building, these rights may currently be transferred to the constructors through TOKI and so on [26]. Anything could be done to cultural entities and the silhouette of Istanbul could be removed according to that law to his remarks. "Taksim as a symbolic square is being lost. I agree that cultural entities can be nuisances in a way, but they could be restored and sustained according to today's needs. I can say that there is this problem of legal organization. For instance; preservation board has neither enough permanent staff nor time to perform registrations. They do not own the necessary equipment as well" [25].

Muhçu emphasizes the fact that bureaucracy decreases the possibilities for registered historic buildings to be restored by the owners. On the contrary, to Muhçu, governmental bodies should provide leasing or feasible credits of which the payback will have no interest for 10 years or a lower amount of interest for 20 years, or the necessary equipment which has some certain discount price in it. "We had attempted to provide timber for registered cultural entities on $50 \%$ discount price via the ministries fifteen years ago, because it can be done. One can get the timber for a registered historic building to be restored in 15 days after applying for it. We completed legal arrangements related to the issue, but bureaucracy makes the things too hard to cope with" [25].

To Muhçu, depending on their significance, public and big scale projects are supposed to be performed after competition. Participation of relevant actors and community should absolutely be considered during the process as well [27].

Participants are obliged to act according to the competition regulations of the Chamber of Architects and the principles that International Union of Architects notifies. Whereas, Onur claims the issue of urbanization is under the control of the relevant governmental bodies [27].

"New urbanization is a must for UNESCO and SITT areas have been legalized for the first time for renewals (2004), which is included in Management Plan of Renewal Areas. It is also under our control to manipulate the item 5366 as it is a "lancet' and it is the fact that it offers not only opportunities, but also threats in urban transformation. There have been negative criticisms by academicians etc. and socio-economic impacts. There used to be no legal interventions before, but at present we can intervene and we have the chance to protect the building. Renewal Law enables us to adopt an 'integrated/holistic' approach. At present, 40-50-year disproportional growth has come to an end in the neighbourhoods. We can now 
control the illegal income that mahalleli make by their property. Surely, they don't want to quit it, they don't want rental loss. Yet, let's say, a group of single people live thereabouts in very bad conditions. Headship has also a "go-between" mission. Mahalleli tend to be conciliatory in general, though. We can say 5366 has become a "milat" (the birth date of Christ)" [28].

It was strikingly proved that two First Drafts were performed in the same place and these kinds of interventions have constantly been seen around the urban transformation [29]. Fener-Balat-Ayvansaray Derneği (FEBAYDER) as a Non-Governmental Organization (NGO) has strongly been protesting against gentrification and renewal projects resulting in the court case won though.

The director of the French Institute of Anatolian Research (IFEA), Nora Şeni calls the whole formal discourse "langue de bois", like being taken for a ride [30]. Similarly, an official in Head Office of Foundation, Samet Ünal states that "Gentrification and the changes in urban space are "political issues" and Tarlabaşı is a fine example. The entire zone was issued to Çalık Holding. Those historical wooden houses are burned down by arson by their owners because they lack finances to deal with the building. There is such a gap between official bodies and volunteer people who could take the sponsorship for restorations and it could be reformed concerning with the relevant legal items".

A brief look at the present local architecture in town makes it clear to see that it can be absurdly cool and cybernetic to experience gentrification like that proposed in the Project of Haliç Metroway Construction by the architect, Hakan Kıran. It was already designed with its metal suspenses and the body that has no relevance with the visual integrity of this historical town as Prof. Cemal Kafadar strongly emphasized [31]. Also, he brings up the construction of the historical Taksim Topçu Kışlası (Taksim Military Barracks or Halil Pasha Artillery Barracks) criticizing the inappropriate architectural details in terms of the integrity again. Rather, he significantly reminds that subtle understanding in city planning during the Ottoman Period saying, "The aesthetics of daily life was a public service for the Ottomans" [31]. To conclude, it can undoubtedly be claimed that the urban interventions applied in the city today might imply only the dystopia of Ottoman urban politics.

\section{REFERENCES}

[1] Smith, N., New Globalism, New Urbanism: Gentrification as Global Urban Strategy, Antipode, UK\&USA, 34, pp. 427-450. 2002.

[2] Bali, R.N., Tarz-1 Hayat'tan Life Style'a. İstanbul: İletişim Yayınları: 2009.

[3] Hernandez, I. \& Marti, G., The Deterritorialization of Cultural Heritage in a Globalized Modernity, Journal of Contemporary Culture, 1, pp. 92-107, 2006.

[4] Baudrillard, J., Simgesel Değiş Tokuş ve Ölüm. Translated by Oğuz Adanır, 2nd ed., İstanbul: Boğaziçi Üniversitesi Yayınları, 2008.

[5] Baudelaire, C., Modern Hayatın Ressamı. Translated by Ali Berktay, 5th ed., İstanbul: İletişim Yayınları, 2009.

[6] Yavuz, N., Gentrification Kavramını Türkçeleştirmekte Neden Zorlanıyoruz? In İstanbul'da Soylulaştırma Eski Kentin Yeni Sahipleri, eds., David Behar and Tolga İslam, 4069. İstanbul: İstanbul Bilgi Üniversitesi Yayınları, 2006.

[7] Deleuze, G. \& Guattari, F., Anti-CEdipus, Translated by Robert Hurley, Mark Seem \& Helen R. Lane. Vol. 1 of Capitalism and Schizophrenia. 2 vols. 1972-1980. London and New York: Continuum, 2004.

[8] Frisby, D., Cityscapes of Modernity: Critical Explorations. Cambridge: Polity Press, 2001. 
[9] Bakhtin, M.M., The Dialogic Imagination: Four Essays by M. M. çev. Emerson, Caryl ve Holquist, Michael, Texas: University of Texas Press, 1981.

[10] Keyder, Ç., Yirmibirinci Yüzyıla Girerken İstanbul. In İstanbul Nereye? Küresel Kent, Kültür, Avrupa, eds., Deniz Göktürk, Levent Soysal and İpek Türeli, pp. 49-61. İstanbul: Metis Yayınları, 2010.

[11] Bayrakdar, D. \& Akçalı, E., In İstanbul Nereye? Küresel Kent, Kültür, Avrupa, eds., Deniz Göktürk, Levent Soysal and İpek Türeli, p. 216, p. 231. İstanbul: Metis Yayınlar1, 2010.

[12] Connerton, P., How Societies Remember, Cambridge: Cambridge University Press, 1989.

[13] Perouse, J.F., İstanbul'la Yüzleşme Denemeleri, Çeperler, Hareketlilik ve Kentsel Bellek, İstanbul: İletișim Yayınlar, 2011.

[14] Interview with Çalıhan, M., Mukhtar of Hoca Gıyaseddin Neighbourhood in Süleymaniye, 28.6.2012.

[15] http://www.radikal.com.tr/turkiye/1095967.

[16] whc.unesco.org veya whc36-russia2012.ru.

[17] whc.unesco.org/document/123045).

[18] Kocabaş, A., Kentsel Dönüşüm(Yenileştirme): İngiltere Deneyimi ve Türkiye'deki Beklentiler. İstanbul: Literatür Yayınları, 2006.

[19] Kuyucu, T. and Ünsal, Ö., In İstanbul Nereye? Küresel Kent, Kültür, Avrupa, eds., Deniz Göktürk, Levent Soysal and İpek Türeli, 85-106. İstanbul: Metis Yayınları, 2010.

[20] CNN Turk 28.7.11

[21] Mestrovic, S.G., Postemotional Society, London: Sage, 1997.

[22] Interview with Gümüş, K., 12.6.2012.

[23] Pickard, R., European Cultural Heritage. A Review of Politics and Practice. Strasbourg: Council of Europe Publishing, 2002.

[24] Işın, E.F., Bir Şehrin Ruhu: Hüzün, Keyif, Hasret. In İstanbul Nereye? Küresel Kent, Kültür, Avrupa, eds., Deniz Göktürk, Levent Soysal and İpek Türeli, pp. 62-79. İstanbul: Metis Yayınları, 2010.

[25] Kanal a 24 May 2012.

[26] Interview with Muhçu, 15 Jan. 2013.

[27] Interview with Muhçu, 25 Jan. 2013.

[28] Interview with Onur, 22 Jun. 2012.

[29] emlakkulisi.com 28 Jul. 2012.

[30] Interview with Şeni, 22 Jun. 2012.

[31] Talk show on CNN Turk, 28 Jul. 2011. 